\title{
Professional and Creative Development of Natural Geographic Course Teachers within the Process of Professional Retraining
}

\author{
Galina Savelevna Samigullina ${ }^{1}$, Syriya Irekovna Gilmanchina ${ }^{1}$, Ilgisar Timergalievich Gaisin ${ }^{1}$, Iskander \\ Rafailevich Gilmanshin ${ }^{1} \&$ Akchurina Ilsia Rafailevna ${ }^{1}$ \\ ${ }^{1}$ Kazanski Federal University, Kazan, Russia \\ Correspondence: Galina Savelevna Samigullina, Kazanski Federal University, Kremlevskaya str., 18, 420008 \\ Kazan, Russia.
}

Received: November 12, 2014

Accepted: December 22, 2014 Online Published: March 29, 2015

doi:10.5539/ies.v8n4p159

URL: http://dx.doi.org/10.5539/ies.v8n4p159

\begin{abstract}
The purpose of this article is to analyse the professional and creative development of natural geographic course teachers of the Republic of Tatarstan in the process of professional retraining. The method for work performing is a retrospective analysis of professional retraining of natural geographic course teachers within the higher professional education system. The creative potential development of natural geographic course teachers is based on the paradigm of preserving the fundamental nature of the Russian education as a process aimed at integrating natural geographic courses and forming a complete picture of the world in order to foster flexibility, versatility of scientific thinking, different ways of reality reproduction, creating an internal focus in self-development and self-organization throughout life. Findings of the study are represented by a professional retraining system of natural geographic course teachers under conditions of education reforming, which contributes to the professional development of teachers.
\end{abstract}

Keywords: fundamentality, professional and creative development, professional training of natural geographic course teachers, system of higher professional education, creative potential

\section{Introduction}

In the fundamental documents identifying the development strategy of the national education system, "National Doctrine of Education of the Russian Federation" and "Concept of Modernization of Russian Education for the Period up to 2015", there is highlighted the exceptional role of education in the development of individual's potential. Education is designed to not only give a person the necessary amount of knowledge and skills, but also to contribute to the realization of his or her creative potential.

Under the conditions of proclaimed humanization of the Russian education content, there is a threat of losing creative potential of basic sciences, reducing the existing gap between theoretical knowledge and activities, converting the logical form of scientific knowledge into the activity-based form.

Creative potential development of natural geographic course teachers is being built by us on the paradigm of preserving the fundamental nature of Russian education.

The notion of fundamentality does not possess a unified interpretation. In Russian pedagogy, pedagogy is understood as a certain range of questions on the fundamental areas of expertise; way of specialist training that meets the requirements of training STR; category of education and education of an individual.

We adhere to certain fundamentality, as a process aimed at integrating natural geographic courses and becoming a complete picture of the world in order to foster flexibility, versatility scientific thinking, different ways of reality reproduction, creating an internal orientation in self-development and self-organization of lifelong learning, inclusion into project activities (Curtis, 2002).

Under the creative potential we understand a complex integrative professional and personal phenomenon, comprising components (motivational-value, theoretical and analytical, reflective-projecting), finding its expression in the holistic development of an appropriate level of creativity (theoretical, reproductive and creative, creative and reproductive and authorial), type (reproductive, constructive, innovative, creative) and the position of creative teachers (observer, participant, analyst, researcher); holistically causing the willingness of a teacher to productive (effective) teaching activities (Samigullina, 2013). 
Under the professional and creative development of natural geographic course teachers we understand the process of personality formation, aimed at high creative pedagogical achievements, mastering creativity and realized throughout a personality self-development, creative teaching activities and professional interactions; the process of teacher's ascension from the theoretical level through reproductive-creative and creative-reproductive ones to the highest level of his development-an authorial one (McKenzie, 2005).

Thus, the professional and creative development of natural geographic course teachers is associated by us with the preservation of fundamental nature of the Russian education under condition of Russia's entry into the Bologna agreement, the formation of a unified world picture and professional interaction, activity approach (Education Committee, 1997).

\section{Materials and Methods}

In the course of activating the process of development of creative potential of natural geographic course teachers during the process of professional retraining, there is presented a principle of interactive learning, which creates cooperation in training, due to the introduction of group project work, involving the development of a post-cycle period at the stage of self-education.

While implementing this principle, we took into account, first, the change of the traditional model of knowledge transfer into the dialogic learning, and secondly, the objective isolation of teacher, paying attention to the dynamic performance: creative growth, creativity and its implementation, innovation and initiative. Third, the possibility of group forms include the ability to create their own socially important projects, become the subject of activity, that is based on the objective to identify the specific problem, the ways and means of addressing them, take responsibility for the results and consequences of the organized activities. Fourth, given the complexity of the courses integration possessing different methods of perception, the time frame of study, course preparation process gives a real chance for teachers of biology, geography, chemistry to combine professional efforts on forming a unified scientific picture of the world in real-time mode (Samigullina, 2012).

According to Krajewski, the substantive content of education is a pedagogically adapted system of scientific knowledge, ways of life, the experience of different types of creative activities, experience of emotional and valuable attitude to the world (Krajewski, 2003).

In the practice of teaching geography, biology, chemistry, and physics, the main idea of the educational content selection and learning process organization is to transmit to the students the basics of scientific geographical, biological, etc. knowledge, where the dominance of the scientific character principle is preserved (Gilmanshina, 2003).

As for the experience of creative activity in practice, it is not realized.

To ensure the modern quality of biological, geographical, chemical school education in the country, it is necessary to pay special attention to the formation of skills how to apply the obtained knowledge to new situations, compare, establish causal relationships, perform practice-and personal-oriented tasks (Maclean, 2007).

There was almost no experience of professional retraining under conditions of planned economy. Until the 90-ies of the twentieth century, there existed a career development system for natural geographic course teachers, which contributed to the professional development of teachers in response to changing conditions. It was relatively stable and resistant to organizational forms, but rather mobile in the content, modifying and updating according to the changes of content, forms and methods of the natural geographic school education (Samigullina, 2012).

Integration of the career development system and higher professional education contributed to the increase of the theoretical level of professional retraining of the natural geographic course teachers.

Qualified lectures on the theory and methods of teaching the subjects of natural and geographical cycle as well as the actual problems of education are taught by professors and scientists of the Kazan (Volga Region) Federal University.

Biology, geography, chemistry teachers take an active part in the preparation and conduct of the all-Russia, national and regional conferences, travelling seminar concerning the training problems; scholar conferences and Olympiads; demonstrate professional mobility: "Continuity within the ecological and geographic education", "Actual problems of teaching natural geographic course methods in schools and universities", "Improved methods of teaching geography and the environment at school and university", "Modern problems of population geography and the labour market", "Innovative educational technologies in the educational process in schools and universities", "Guidelines for improving the efficiency of the educational process in educational institutions"; 
"Actual problems of geography teaching in schools and universities", "Geography in a multicultural world" (2010, 2014), and others.

In our opinion, the modern educational situation requires a teacher model that not only meets the standard norms, but also is ready to abandon the usual schemes and stereotypes in behaviour, perception and thinking (Scanlon, 2011).

Involvement into the development of complex multiscale educational programs necessitates enrichment of experience in creative activity of a modern teacher through the theoretical and methodological, design, structural and methodical, professional, active, diagnostic, research, predictive knowledge and skills, with the ultimate aim of which is to identify justified approaches, ideas, their output beyond the subject of federation and movement into the federal component of the standard.

Currently, in the republic there are author programs in biology, geography, chemistry, emerged beyond the frames of the educational institution participants and included into the collection of the best methodological developments of teachers in Russia.

The new millennium was marked by the integration of higher professional education system, advanced vocational training and professional retraining of teachers of natural geographic courses for the purpose of efficient use of resources, the system of scientific and methodical work, professional development of all educators, not least resource specialist, educators-andragogists of the qualification improvement system; strengthening the alliance between professional retraining institutions and scientists; integration of school and university; introducing an individual learning mode for teachers using new information technologies (Rhoton, 2001).

As a part of the personal-activity and individual-creative approaches to the development of creative potential of the natural geographic course teachers, we consider a teacher's personality as a subject of the professional retraining process.

\section{Results}

Targeted, content-rich, procedural characteristics of the educational process developed in accordance with the holistic, didactic and paradigmatic representation of the essence of professional creative development of a natural geographic course teacher and organization of his development.

As an example of the effectiveness of professional retraining in areas of "biology", "geography", "chemistry" we carried out a sociological survey of the audience.

For the empirical measurement, we have developed criteria and performance indicators of professional training:

- Teachers' satisfaction with the meaningful and procedural conditions of professional training (emotional and procedural components): students' evaluation of the classes content; forms and methods of the training sessions, demand for the obtained information.

- Results of the final certification: students' assessment of the motivation and incentive role of the courses in general.

Important primary information for us is a state of natural geographic course teachers' satisfaction with the substantial and procedural conditions of professional retraining (emotionally-procedural component). These indicators reflect the listeners' evaluation of the procedural aspects of professional retraining courses (forms and methods of classes in the course of professional retraining, the content of training), and are presented in Table 1. 
Table 1. State of natural geographic course teachers' satisfaction with procedural aspects of professional retraining in the following areas: biology, geography, chemistry (Session 4)

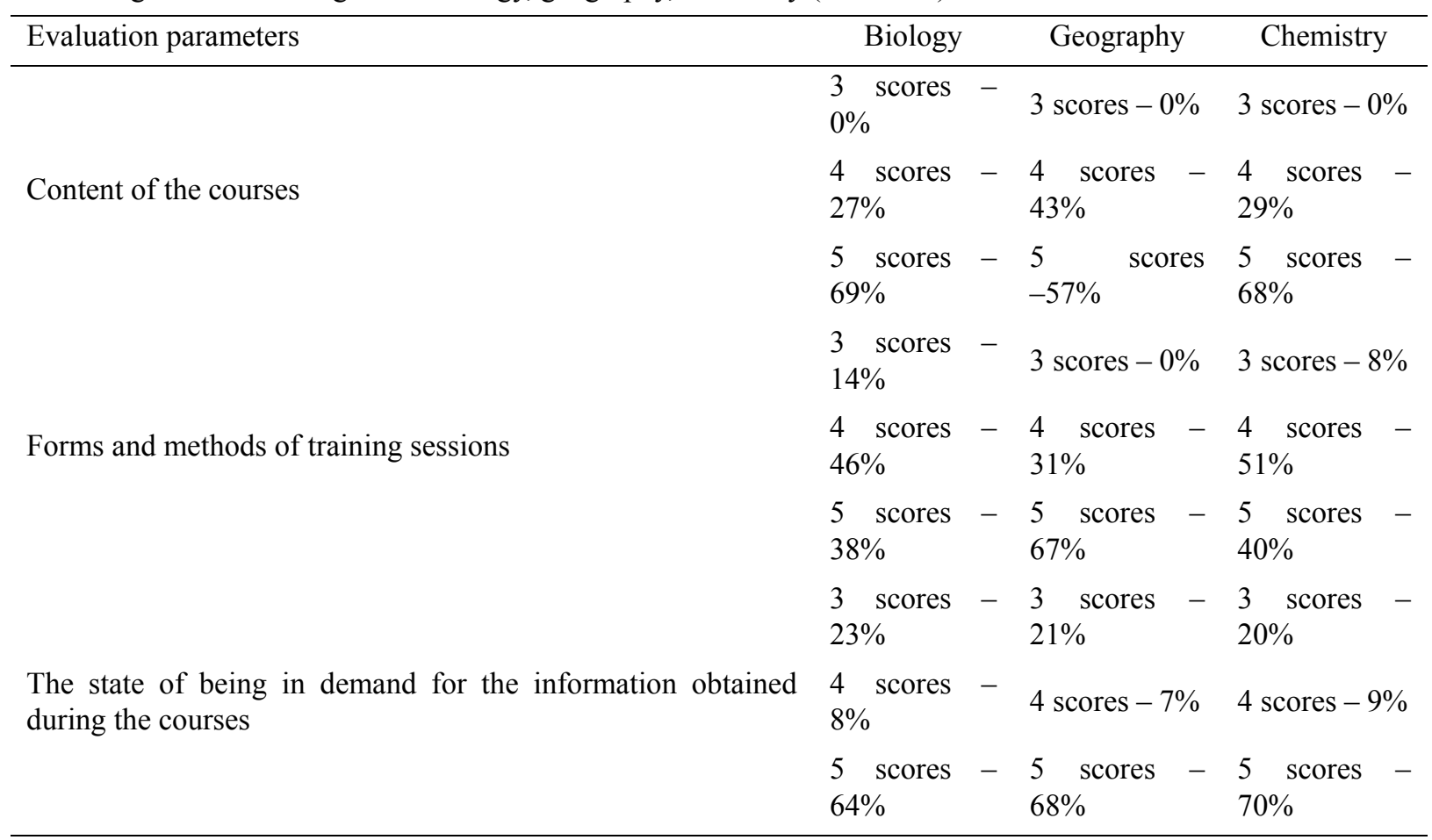

As it is seen from Table 1, the satisfaction level of students with professional retraining courses is high enough. Therefore, we can say that among the surveyed trainees there is no one who has expressed complete dissatisfaction with the procedural aspects of the professional retraining.

Table 2. Students' suggestions as for professional retraining improvement

\begin{tabular}{|c|c|c|c|}
\hline $\begin{array}{l}\text { Suggestions } \\
\text { improvement }\end{array}$ & Biology & Geography & Chemistry \\
\hline $\begin{array}{l}\text { content of the } \\
\text { professional retraining } \\
\text { courses }\end{array}$ & $\begin{array}{l}\text { - Request for considering } \\
\text { the teachers' training degree } \\
-2 \text { persons, }(15 \%) \text {; } \\
\text { - Desire to learn about the } \\
\text { themes and methods of the } \\
\text { biology and ecology } \\
\text { researches with pupils - } \\
8 \% \text {. }\end{array}$ & $\begin{array}{l}\text { - More attention should be } \\
\text { paid to the preparation for } \\
\text { the Uniform state exam - } \\
7 \% \text {; } \\
\text { - Active forms of work. }\end{array}$ & $\begin{array}{l}\text { - Request for considering } \\
\text { the teachers' training } \\
\text { degree }-7 \% \text {; } \\
\text { - Desire to learn about the } \\
\text { themes and methods of the } \\
\text { chemistry researches with } \\
\text { pupils }-10 \% \text {. }\end{array}$ \\
\hline $\begin{array}{l}\text { forms, methods and } \\
\text { technologies r of } \\
\text { professional retraining } \\
\text { courses }\end{array}$ & $\begin{array}{l}\text { - Individual approach - } \\
23 \% \text {; } \\
\text { - Distance learning }-16 \% \text {. }\end{array}$ & $\begin{array}{l}\text { - Excursions }-7 \% \\
\text { - Electronically performed } \\
\text { lectures }-7 \% \text {; } \\
\text { - Visiting schools }-21 \% \text {. }\end{array}$ & $\begin{array}{l}\text { - Individual approach - } \\
6 \% \text {; } \\
\text { - Distance learning }-20 \% \text {. }\end{array}$ \\
\hline
\end{tabular}

Thus, high levels of emotional and procedural component of professional retraining reflect the importance of the subjective-practical relation to the forms of audience and content aspects of the educational process. These indicators and their values reflect the opinions of students and teachers as the degree of "saturation" of the respective needs and requirements, defining the nature and objectives of the courses.

Information-cognitive effect of professional retraining is considered by us as an indicator of reflecting a balance of professional and personal interests of students and their evaluation from these positions of the demand level for the 
obtained information (see Table 2).

As a result, the information-cognitive effect indicators confirmed the general tendency of positive evaluation of the professional retraining content by the listeners, so it is possible to speak of a sufficiently high level of correspondence between the content of courses and professional needs of natural geographic course teachers.

Despite the rather high evaluation of the professional retraining, we have carefully studied listeners' suggestions on their organizations, in particular on the represented forms of distance learning and the implementation of an individual approach.

Professional retraining of natural geographical course teachers is accompanied by research work, the development of scientific and methodological guidelines, complexes, etc. On the experiment stage there were developed numerous recommendations of the training and methodological support for the transition to specialized education; system-didactic complex of the professional retraining of natural-geographic course teachers, including "Software and methodological support of professional training and retraining of geography and related course teachers", "Short course of lectures for geography teachers", a workshop "Reflective-analytical work of a geography teacher", etc.

In order to introduce the individual learning mode, there were developed modules of remote advanced vocational training (professional retraining) "Diagnosis of readiness of a geography and related course teacher for creative pedagogical activity", "Diagnosis of teacher's professional difficulties with the implementation of interdisciplinary connections", "Diagnosis of teacher's readiness to implement the competency approach", "Informational and educational environment of geography teaching under condition of FSES-2010 adoption".

It is appropriate to recall that the German philosopher Arnold Gehlen drew attention to the fact that the gap of direct links between people, replacing them with indirect and remote ones may violate the systems of operational (sensory) response to the transformation challenges, and that human emotions effectively express themselves only within the range of the direct communication and not at a distance.

That is why, despite the fact that Internet technologies form a new creative space, virtual communication cannot replace direct contact between people. Classroom forms of work erode professional isolation of teachers, but the insides of the pedagogical phenomena seem to be hidden, using this method, it is impossible to ensure full objectivity of information (Alan, 2008).

We conclude that the best is a combination of classroom and distance learning, both to the intellectual development of the individual and comparing the level of individual educational achievements (Rozendaal, 2002; Broomes, 1997).

\section{Discussion}

Problems of professional retraining are closely linked with the main purpose of adult education, formulated by the International Commission of UNESCO on Educational and Training Issues for the XXI Century-teach people how to independently obtain their knowledge (Gargano, 2003; Brookfield, 1991). Professional and creative development of natural geographic course teachers is associated by us, besides saving fundamental Russian education, with the formation of a unified picture of the world and professional interaction (American Federation of Teachers, 1995; MacCulloch, 1999). Given the complexity of the integration of disciplines, with different methods of learning, the time frame of study, the course preparation process gives a real chance for teachers of biology, geography, chemistry to combine professional efforts, to form a unified picture of the world in real time mode with the preservation of individual style in continuing education, the implementation of Bologna agreement ideas (Evlanova, 2009; Byers, 1997). Development of creative potential of natural geographic course teachers cannot be reduced to a simple work out of the new, for example, research or diagnostic methods within teaching activities and expansion in this regard of their cognitive space. These are only the necessary conditions that must entail deep, intrinsic changes in the professional and personal motivation and values, epistemological orientations of teacher, his analytical and assessment activities, constructive behaviour. For each teacher this process, subject to the general tendencies, will be carried out in its own way, taking into account individual characteristics and realization conditions, being a personal characteristic (Alan, 2005). The factors, determining the uniqueness (nature) of manifestation and development of creative potential of natural geographic course teachers, in our view, include the personal factor, which forms the theme, the dominant analytical needs and activity in the development of creative potential; analytical orientation of the teacher as a set of methodological ideas, target objectives that have become a benchmark and a scientific tool for all teaching activities; assessment activities as ongoing analysis and self-analysis of the results of personal activities, the development of creative potential; investigatory component reflecting the structural solutions for 
the specific problems of pedagogical situations by means of investigatory search (Rhoton, 2006). Formation and development of the creative potential of natural geographic course teachers as a holistic professional and personal phenomenon is carried out through various forms of self-manifestation of personality: self-knowledge-orientation in the value-semantic content of individual behaviour (the definition of a teacher himself, his place in the social present, past and future); self-development-the ability to implement a holistic development of their personality, based on the definition of objectives and means of implementation; self-realization-the real action, the embodiment of the values and meanings in teaching activity; self-projecting-mental personal projection into the future, a specific plan of teachers' activities in time (professional plans); self-organization-the ability to subordinate yourself, your actions to the achievement of a specific goal; introspection-the ability to analyse your personal "I", the results of teaching activity; self-regulation-the ability of individual teachers to monitor and adjust their experience (Andreev, 2000).

\section{Conclusion}

Result analysis of the integration of professional retraining of the natural and geographic course teachers into the system of higher professional education shows that the emerging system of professional retraining of natural geographic course teachers in terms of education reforming promotes professional and creative growth of teachers.

Given the complexity and multidimensionality of the problem of development of creative potential of the natural geographic courses teachers in retraining, the study does not claim to its comprehensive and complete perfection. However, the experimental development of professional training with the intercourse period within which we developed a pedagogical model, currently allows to productively addressing the development of the creative potential of the teachers in the course of professional retraining on evidence-based and practice-oriented basis, which gives us a hope for a successful solution of subsequent problems.

As recommendations it is necessary to pay attention to integration of the higher vocational training and professional retraining, the system approach on is professional-creative development of teachers of is natural-geographical disciplines in the course of professional retraining by integration tools of the knowledge which are absent in the Russian general education.

The system approach to development of creative potential of teachers of is natural-geographical disciplines by integration tools of disciplines represents scientific interest and allows to concretize essentially conditions of perfection and an estimation of results of training at metasubject, personal and subject levels of mastering.

\section{Acknowledgements}

The author's project by Samigullina, G.S., used in the process of professional retraining of the natural geographic course teachers "Technology development and use of complex integrated tasks" is honoured in the IX republican competition " 50 best ideas for the Republic of Tatarstan" in the category "Innovation in Education" in the direction of "technical professional education".

\section{References}

Alan, B., \& Stoller, F. (2005). Maximizing the benefits of project work in foreign language classrooms. Forum: English teaching forum, 4(43), 10-21.

American Federation of Teachers. Principles for Professional Development. (1995). Washington, D.C.

Andreev, V. I. (2010). Pedagogics of creative self-development in a context of innovational principles, competitiveness and prognoses. Materials of XX whole Russia's scientifical conference-Kazan.

Broomes, D., Cumberbatch, G., James, A., \& Petty, O. (1995). Teaching primary school mathematics. Kingston, Ian Randle Publ.: UNESCO, VI.

Curtis, D. (2002). The power of projects. Educational leadership, 1(60), 50-53.

Evlanova, L. (2009). Improving the individual teacher's activity style within the system of continuing education. Dissertation of the candidate of pedagogical sciences, Novosibirsk.

Gillard, D. (2007). Education in England: A brief history. London: David Fulton Publishers.

Gilmanshina, S. I. (2013). A new look at the professional teacher thinking. International Journal of Applied and Fundamental Research. Retrieved from http://www.science-sd.com/455-24187

Krayevskiy, V., \& Khutorskiy, A. (2003). The objective and general objective issues in educational standards. Pedagogy, 2, 3-10. 
Maclean, R. (2007). Learning and Teaching for the Twenty-First Century: Festschrift for Professor Phillip Hughes. Springer Science \& Business Media. http://dx.doi.org/10.1007/978-1-4020-5773-1

McKenzie, P., \& Santiago, P. (2005). Teachers matter: Attracting, developing and retaining effective teachers. Organisation for Economic Co-operation and Development.

National Standards for Headteachers. (2004). London: Department for Education and Skill.

Rhoton, J., \& Shane, P. (2006). Teaching Science in the $21^{\text {st }}$ Century. NSTA Press.

Roberts, A., \& Falkenberg, B. (2007). New Chronology with Mental, Historical and Geographical Connections (pp. 47-65). Middlesex University resource.

Rozendaal, J. (2002). Motivation and information processing in innovative secondary vocational education. Leiden.

Samigullina, G. (2013). Creative potential development of the natural science teachers within the advanced training system. Kazan: Otechestvo.

Samigullina, G., \& Gaisin, R. (2012). Integration of higher professional education and advanced training of geography teachers in the Republic of Tatarstan. Modern studies of social problems, 4. Retrieved August 27, 2014, from http://sisp.nkras.ru/e-ru/issues/2012/4/gaisin.pdf

Scanlon, L. (2011). “Becoming” a Professional: an Interdisciplinary Analysis of Professional Learning. Springer Science \& Business Media. http://dx.doi.org/10.1007/978-94-007-1378-9

Sibgatova, K. I., Gilmanshina, S. I., Khalikova, F. D., Gilmanshin, I. R., Akchurina, I. R., Shchaveleva N. G., \& Fassakhova, G. R. (2015). Peculiarities of Pupils and Vocational College Students' Career Guidance Modeling in the Integrated System "School-College-Enterprise". Asian Social Science, 11(1), 386-391.

The Magna Charta of University. (2003). The website of Summit on Bologna Process in Berlin.

Zotova, N. K. (2013). The personified model of improvement of professional skill of educators in modern socially economic conditions [Electronic resource]: The collective monography. M.: FLINTA.

\section{Copyrights}

Copyright for this article is retained by the author(s), with first publication rights granted to the journal.

This is an open-access article distributed under the terms and conditions of the Creative Commons Attribution license (http://creativecommons.org/licenses/by/3.0/). 